\title{
NUMERICAL INVESTIGATIONS OF FLUSHING TIME IN SMALL MARINAS
}

Scientific paper

Ivana Bartolić

(Received: 24 August 2020; accepted: 4 December 2020)

Zagreb University of Applied Sciences, Department of Civil Engineering, Lecturer

Corresponding author: ibartolic@tvz.hr

Goran Lončar

Faculty of Civil Engineering, University of Zagreb, Full Professor

Damjan Bujak

Faculty of Civil Engineering, University of Zagreb, Postdoctoral researcher

Dalibor Carević

Faculty of Civil Engineering, University of Zagreb, Associate Professor

\begin{abstract}
This paper presents the results of $2 \mathrm{D}$ and $3 \mathrm{D}$ numerical simulations of sea circulation and water mass exchange for a marina with hypothetical dimensions $(L / B=2$ and $L / B=0.5)$ to calculate the return flow factor. The return flow factor $b$ was analyzed in relation to the marina entrance width, sea current velocity outside the marina $(0,1,2$, and $5 \mathrm{~cm} / \mathrm{s})$ and the sea surface level oscillation dynamics. The basic comparative parameter is the eflushing time, $T_{f}$. The intensity of forced circulation is calculated to achieve time $T_{f}$ of less than 10 days. The impact of the wind field on the e-flushing time for different marina widths was analyzed using a 3D numerical model. The numerical simulation results indicate that the e-flushing time $T_{f}$ depends on the amplitude of the tidal signal, secondary to the width of the marina inlet, and the smallest amount on the velocity field in the outer region. Conversely, the return flow factor $b$ depends on the width of the marina entrance, less on the tidal signal amplitude, and least on the current velocity outside the marina if currents are $\geq 1 \mathrm{~cm} / \mathrm{s}$. Forced circulation of $1 \mathrm{~m} / \mathrm{s}$ is only required for the marina with a smaller tidal amplitude (position Dubrovnik) to achieve $T_{i}<10$ days. If at the observed location wind is a dominant sea circulation generator, a wider marina entrance will allow faster sea exchange.
\end{abstract}

Keywords: Return flow factor; marina flushing; entrance width; tidal range; wind; Adriatic Sea; numerical model. 


\section{INTRODUCTION}

The primary role of marinas and ports is to protect vessels from undesirable effects caused by waves, and it is achieved by constructing a breakwater. Breakwaters reduce natural circulation between the marina and surrounding seawater. In Croatia, the largest number of marinas and harbors are protected by rubble mound breakwaters; thus, seawater within a marina is separated from the surrounding seawater, and natural circulation is reduced. The state of water quality within a semi-enclosed water area (marina/port/harbor) is a major environmental concern, and it predominantly depends on water exchange and sea water circulation in the marina basin.

The water renewal rate in human-made or naturally semi-enclosed basins is conditioned by seawater circulation generators (e.g., wind, waves, tides, inner freshwater discharge, etc.) [1-4]. Most approaches for seawater renewal estimation are built around tides as a predictable factor. Depending on the geographical location, one or more of these factors may dominate the water mass exchange in the marina. Structural features, such as the planform geometry of a port, entrance width, water depth, bed slope, etc., influence the water renewal efficiency [3-5]. In [3], the efficiency of the water mass exchange between the marina and the surrounding water body was thoroughly investigated, depending on the structural features and tides. An efficient water mass exchange performance for rectangular ports/marinas with one asymmetrical entrance is achieved when the ratio of length $L$ (parallel to the coast, in the direction of sea currents outside the marina) to width $B$ is close to unity (acceptable ratios are in the range $1 / 2<L / B>2$ ). For marinas with an asymmetric entrance, it is recommended that the marina entrance should be positioned parallel to the long axis of the marina basin. In marinas, where the ratio in the range $1 / 2<L / B>2$ is not achieved, two or more circulation cells can form and decrease the volume of the basin that can be flushed (especially in the parts of marina far from the entrance). Extrapolation of these results to a tidal range smaller than $1.2 \mathrm{~m}$ has not been confirmed in the scientific literature. To achieve a good marina flushing rate, the relationship between the area of basin $A$ and cross-sectional area of entrance opening a (A/a) should be greater than 200, ideally 400 [6]. This ratio ensures better mixing and water mass exchange because of the relatively high inlet velocity and turbulence formation. A similar process occurs during the low tide when seawater exits the port, because higher velocities enhance efficient mixing of seawater with the surrounding "new" water. In areas where the tidal range is small and the sea exchange process is governed by wind currents, it is recommended that the marina entrance should be designed as wide as possible, and be positioned in the direction of the prevailing wind [7].

Pipe culverts in the breakwater body [8] or forced circulation are used to achieve better circulation and reduce water stagnation in semi-enclosed basins and areas with small tides. Research on the physical model forced by waves $[9,10]$ has shown that faster water flows are observed when the axis of the flushing culvert is placed at the mean sea level in comparison with a fully submerged culvert. However, if the culvert is completely submerged, the transmission of wave energy becomes small [8]. Research at $\mathrm{ACl}$ marina Opatija suggests that the flow rate in the culverts achieved by the action of natural generators is reduced almost twice when the culvert is completely submerged compared to partially submerged. Therefore, in areas of small tidal oscillations, it is recommended that a group of culverts on two levels should be designed, where the upper group of culverts is at the middle sea level [8]. The aim of the flushing culverts in the breakwater body is to ensure that water masses exchange between the marina and surrounding water body while the forced circulation (by the low-pressure pump) pumps "clear" water outside the marina into the marina basin. However, the cost, maintenance, and power consumption of the pump affect the forced circulation. The advantage of the pump, compared to flushing culverts, is that the pump does not require the construction of the opening in the breakwater body, thereby achieving greater stability, and there is no transmission of wave energy through the culverts.

This study investigates seawater exchange and circulation in hypothetical marinas on the eastern coast of the Adriatic Sea (Rovinj and Dubrovnik). The Adriatic Sea is a part of the Mediterranean Sea where the sea tides are semidiurnal. They are the result of the combined effect of local gravitational attraction of the Moon and the Sun, and the tidal forcing from the Atlantic Ocean that penetrates through the Strait of Gibraltar. Tides in the Mediterranean Sea have amplitudes of the order of a few centimeters [11]. The exception is the Adriatic Sea, Aegean Sea, and Gulf of Gabès, where tides have significant ranges and are amplified by resonance phenomena [12]. The mean daily amplitudes of tidal oscillations, based on long-term measurements of sea level along the eastern Adriatic coast, were calculated to be $22 \mathrm{~cm}$ in Dubrovnik, $23 \mathrm{~cm}$ in Split, $25 \mathrm{~cm}$ in Zadar, $30 \mathrm{~cm}$ in Bakar, and $47 \mathrm{~cm}$ in Rovinj. 


\section{MATERIALS AND METHODS}

\subsection{Analytical formulas for determining water exchange characteristics of the marina basin}

Hydrodynamic time parameters are used to quantify the water mass exchange efficiency in semi-enclosed water basins. In previous research, a functional relationship was observed between the time required to exchange seawater from the marina basin with the "clear" sea outside the marina and the risk of contamination [13]. Studies have been conducted to analyze various adverse effects on the ecosystem, such as harmful algal blooms. Increasing seawater exchange has a positive effect on water quality within the semi-enclosed basin [13]. E-flushing time $\left(T_{f}\right)$ is an integrative parameter that describes the general exchange characteristics of a waterbody without identifying the underlying physical process and is described with the equation:

$T_{f}=\frac{V_{A K}}{Q_{A K}}$

where $V_{A K}$ is the volume of water in the defined (bounded) system and $Q_{A K}$ is the volumetric rate through the system [10]. Equation 1 shows the basic form of water mass exchange estimation, assuming instantaneous and uniform mixing within the waterbody and excluding the possibility that seawater that exits the basin during the previous low tide may partially return to the basin during the next high tide. This formulation does not rely on any natural generator (such as tides, waves, or wind) but rather provides a general flow rate through the control volume. Because the quantities $V_{A K}$ or $Q_{A K}$ are often not known, the computation of $T_{f}$ is sometimes based on the assumption that the waterbody functions as a continuously stirred tank reactor (CSTR), so that e-flushing time can be estimated from the observation of the outflow concentration over time [13]. The CSTR model assumes that any introduction of mass is instantaneously and evenly mixed throughout the domain [14]. Therefore, the concentration of the constituent exiting the system is equal to the concentration inside the CSTR. Simply, it is a mass conservation equation with the assumption of a uniform spatial distribution of pollution within the control volume, which can be represented by the following equation:

$C(t)=C_{0} e^{-\left(\frac{Q_{A K}}{V_{A K}}\right) t}=C_{0} e^{-t / T_{f}}$

where $C$ is the instantaneous concentration at time $t, C_{0}$ is the initial concentration within the control volume, and $t$ is the elapsed time. Owing to the form of the mathematical formulation, the introduced mass cannot completely leave the system, and the concentration cannot reach a value equal to zero, even after an infinite time. To avoid the aforementioned deficiency of the model, the reference value for the comparison between the solutions after $T_{f}$ time is $37 \%$ of the initial $C_{0}$ concentration. According to recommendations of the PIANC [6], the aim is to achieve time $T_{f}$, which will reduce the mean concentration to $37 \%$ of the initial concentration $\left(e^{-1}\right)$, in four days, and such a condition will be "good" If the complete water exchange of the basin is between four and ten days; however, this condition is characterized as "fair" and poor if more time is required.

An alternative classical approach to estimate e-flushing time is the tidal prism method. For this method, tides are assumed to be a dominant water mass exchange generator, and time $T_{f}$ can be calculated according to the following equation $[15,16]$ :

$T_{f}=\frac{V_{A K} T_{p o}}{(1-b) V_{p o}}$

where $b$ is the return flow factor, $V_{A K}$ is the mean basin volume, $V_{p_{0}}$ is the basin volume between high and low tide, and $T_{p o}$ is the tidal period. Therefore, to estimate the amount of the "old water" (which exited the basin during the previous low tide) that returns to the basin, the return flow factor $b$ is used. The magnitude of the return flow factor depends on the oceanographic conditions in the surrounding aquatorium. If $b$ is assumed to be zero, then there is no "old water" entering the basin during high tides.

The analytical models presented by equations (1), (2), and (3) do not consider other natural seawater circulation generators that can have a significant impact in areas of micro-tidal conditions (such as waves, wind, circulation triggered by spatial differences in fluid density, etc.). In addition, the deficiency of these methods is caused by insufficient information regarding the spatial variability and the ability of basins to self-purify by natural processes that generate sea circulation, and thus, the advection of pollution. 


\subsection{Definition of the tested variants and hypothetical marina spatial domain}

This paper presents the results of numerical simulations performed by the circulation model to determine the return flow factor for the marina basin. Numerical simulations were run for a hypothetical marina with length $L=300 \mathrm{~m}$, width $B=150 \mathrm{~m}(L / B=2)$, and vice versa $(L / B=0.5)$, which are common geometry dimensions for the Croatian Adriatic [17]. The simulations were carried out for the following environmental and construction conditions (Figure 1): a) Four marina entrance widths (10 m, $20 \mathrm{~m}, 30 \mathrm{~m}, 40 \mathrm{~m})(2 \mathrm{D}$ model), b) sea currents outside the marina with intensities of $0,1,2$, and $5 \mathrm{~cm} / \mathrm{s}$ (2D model); c) two tidal oscillations amplitudes at two geographical locations (north Adriatic - Rovinj and south Adriatic - Dubrovnik) (2D and 3D model); d) five wind directions ( $\mathrm{N}$ - north, NE - north east, E - east, SE - south east, and S - south; marina has a symmetrical shape; thus, SW - south west, W-west, and NW-north west wind correspond to the SE, E and NE wind); e) conditions with and without wind (models were forced by a daily wind of $2 \mathrm{Bf}$ velocity each day in the period $12-18 \mathrm{~h}$ ).

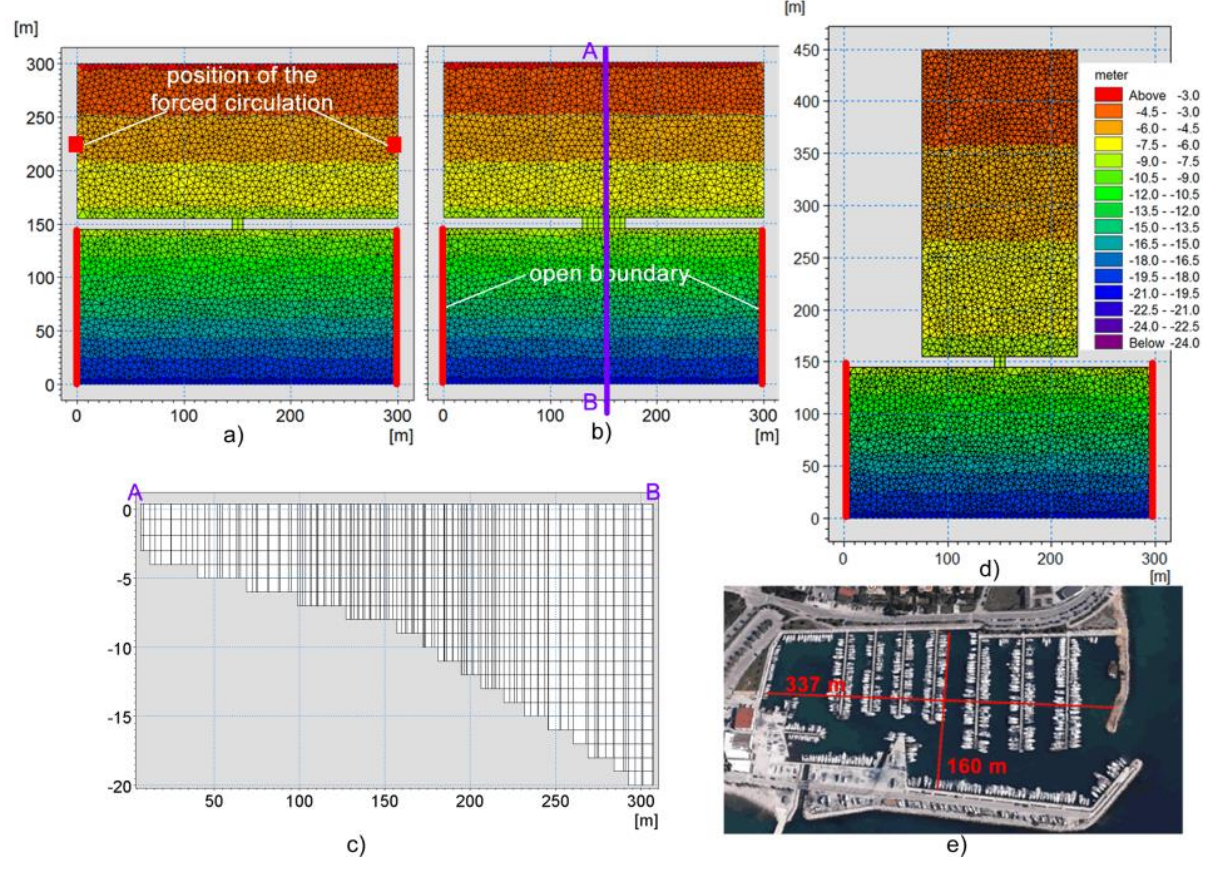

Figure 1 Spatial domain of hypothetical marina: a) marina $L / B=2$, entrance width $10 \mathrm{~m}, \mathrm{~b}$ ) marina $L / B=2$, entrance width $40 \mathrm{~m}, \mathrm{c}$ ) longitudinal cross section $A-B, d$ ) marina $L / B=0.5$, entrance width $10 \mathrm{~m}, e$ ) an example of the real marina $L / B \approx 0.5$ - marina in Zadar

The total volume of the sea exchanged through the marina entrance and e-flushing time $T_{f}$ (thoroughly described in [18]) was used as a comparative parameter for determining the quality of each analyzed solution. The numerical 3D simulations were run with Mike 3fm, and 2D simulations with Mike 21fm [19]. The domain of the hypothetical marina (Figure 1) is horizontally discretized with an unstructured triangular and rectangular finite volume mesh of an average cell area of $15-25 \mathrm{~m}^{2}$. Rectangular cells were used in the entrance area and triangular in the rest of the domain. For the 3D model, in the vertical, 3 sigma layers to a depth of $3 \mathrm{~m}$ and $17 \mathrm{z}$ layers of $1 \mathrm{~m}$ width to $20 \mathrm{~m}$ depth were used [20]. The bed slope is constant, from 3 to $20 \mathrm{~m}$ depth. The depth at the entrance was $8 \mathrm{~m}$. The velocity perpendicular to the vertical impermeable boundary was set to 0 .

\subsection{Initial and boundary conditions}

Sea levels vary during the simulations and are obtained from realistic data based on the amplitudes and phases of the seven basic tidal signal constituents at the locations Rovinj and Dubrovnik [21]. The initial condition for the 2D and $3 \mathrm{D}$ current fields is a steady state. In Mike $3 \mathrm{fm}$, the $k-\varepsilon$ turbulence model [22] was used in the vertical direction and the Smagorinsky [23] scheme in the horizontal direction. Dispersion coefficients for scalar fields of temperature and salinity were specified with a proportionality factor (Prandtl number) of 0.8 in vertical and 0.2 in horizontal (3D model). The proportionality factors for the fields of turbulent kinetic energy $(k)$ and dissipation $(\varepsilon)$ were adopted with 
values $1(k)$ and $1.3(\varepsilon)$ in the horizontal and vertical directions, respectively. The roughness and Smagorinsky coefficients were set as spatially and temporally constant at 0.01 and 0.28 , respectively. The Manning roughness coefficient and Smagorinsky coefficient in the $2 \mathrm{D}$ model were adopted as spatially homogeneous, with values of 0.024 and 0.28 , respectively.

All numerical simulations were carried out for constant temperature and salinity, without density variations. In the 3D numerical models forced by wind, the wind stress coefficient, which models the influence of wind on the sea surface, was defined at 0.0024 [24].

The E-flushing time was estimated as described in Section 2.1. Initially, the tracer solution (non-reactive) was set to " 100 " for the marina aquatorium, and the concentration value "0" elsewhere. Marina flushing causes a decline in the mean concentrations of the tracer solution mass through the mechanism of convective dispersion.

Forced circulation was induced as an intake of new water with a concentration equal to 0 at the two positions shown in Figure 1. The target flow rate is one that allows concentration to be reduced by up to $37 \%\left(e^{-1}\right)$ within 10 days (achieving a condition that is characterized as "fair" [7]). Forced circulation operates only during the night, from 22:00 to 6:00, during the lower tariff of the electricity price.

\section{SEA CIRCULATION MODEL RESULTS}

\subsection{Current velocity field}

The vertically averaged current velocity field in the marina basin varies slightly depending on the phase of the tides (Figure 2). A slightly lower current velocity occurs during high tide at both locations (current velocity field at location Dubrovnik is not shown in this paper). In the case of the $10 \mathrm{~m}$ wide entrance (compared to the $40 \mathrm{~m}$ wide entrance), higher current velocities occur within the marina basin at both locations. Lower current velocities occur at the Dubrovnik site because of the smaller tidal range. Extending the entrance width from 10 to $40 \mathrm{~m}$ causes the current velocity field to change only near the entrance area. The conclusions are the same for marinas with $L / B=2$ and $L / B=0.5$. Higher current velocities appear locally for the $10 \mathrm{~m}$ wide marina entrance (for both Rovinj and Dubrovnik locations), confirming the finding from the literature that at relatively narrow entrances, tides cause flow through the entrance with higher velocities than in the case of wider entrances.

Figure 3 shows the impact of the $\mathrm{N}$ and $\mathrm{S}$ wind on the surface and bottom current velocity fields (3D model) at locations of Dubrovnik (entrance width $10 \mathrm{~m}$ ) and Rovinj (entrance width $40 \mathrm{~m}$ ). The ratio of length $(L)$ to width $(B)$ of the marina was 2 . Wind (all wind directions) causes higher current velocities compared to the models forced only by tides (Figure and 2,3). In the marina entrance profile, baroclinic flow occurs (vertical compensation). In the surface layer, inward current appears under the action of $S$ and SE wind, whereas the outward current under the $\mathrm{N}, \mathrm{NE}$, and $\mathrm{E}$ wind. The layer thickness of the surface inward/outward current is significantly less than the thickness of the compensation bottom layer; thus, the current velocity in the surface layer of the marina entrance is higher.
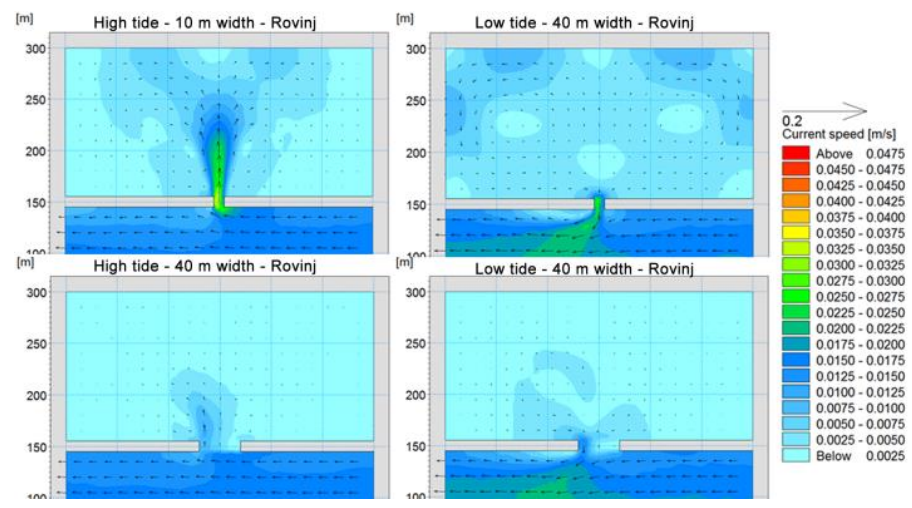

Figure 2 Vertically averaged current velocity fields (2D model) for the 21st hour (low tide) and 28th hour (high tide) of the numerical simulations for $2 \mathrm{~cm} / \mathrm{s}$ sea currents outside the marina, the marina entrance width of 10 and $40 \mathrm{~m}$, location Rovinj, (L/B = 2) 

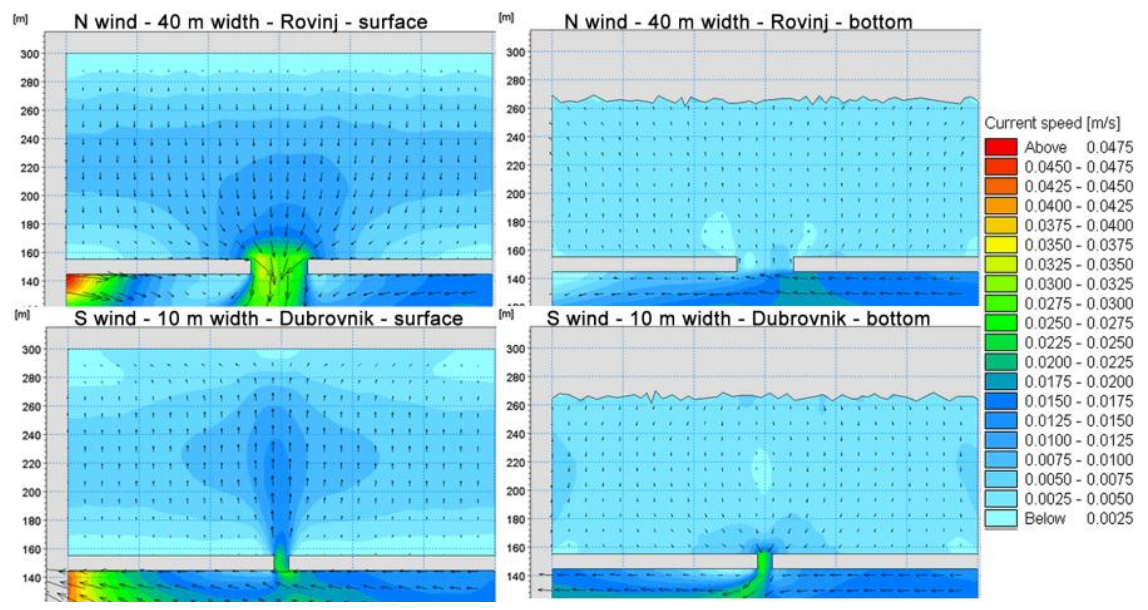

Figure 3 Surface and bottom current velocity fields (3D model) for the 28th hour of numerical simulation at $2 \mathrm{~cm} / \mathrm{s}$ sea currents outside the marina, for the marina entrance width of $10 \mathrm{~m}$, at the location Dubrovnik and the $S$ wind and for the marina entrance width of $40 \mathrm{~m}$, location Rovinj and $\mathrm{N}$ wind (both $L / B=2)$

\subsection{Concentration field}

Figure 4 shows the vertically averaged concentration fields (2D model) at an outer sea current velocity of $2 \mathrm{~cm} / \mathrm{s}$ for the marina entrances with widths of $10 \mathrm{~m}$ and $40 \mathrm{~m}$, and locations of Rovinj and Dubrovnik. The ratios of length to width of the marina are $L / B=2$ and $L / B=0.5$. A smaller vertically averaged concentration of the tracer solution was noticeable in the marina with a $10 \mathrm{~m}$ wide entrance than that with a $40 \mathrm{~m}$ wide entrance, for both locations (Dubrovnik and Rovinj).
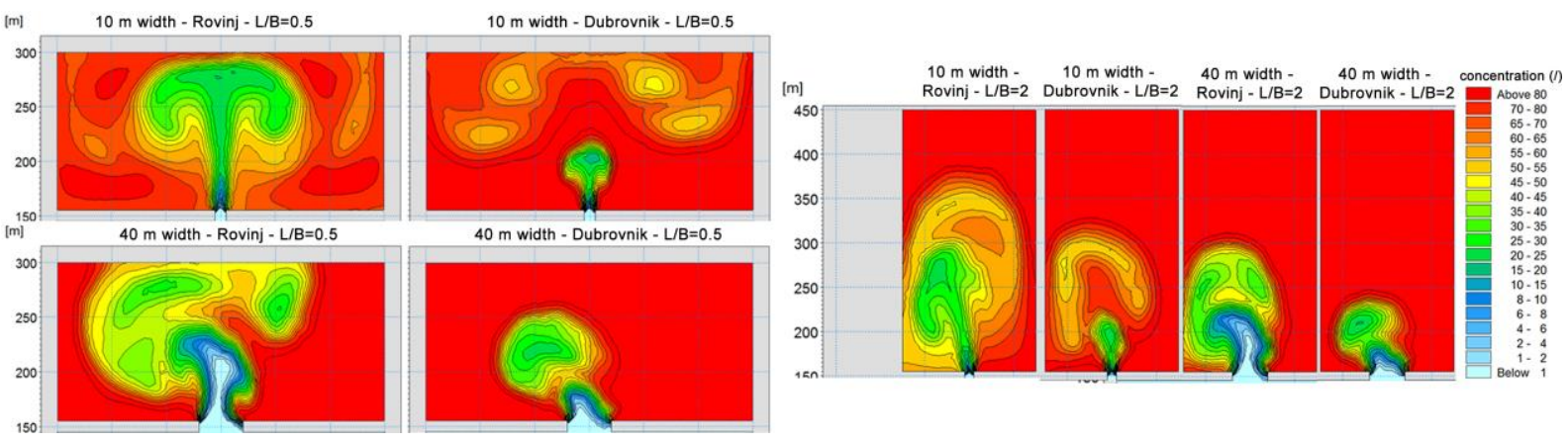

Figure 4. Vertically averaged concentration fields (2D model) for the 48 th hour of numerical simulation at $2 \mathrm{~cm} / \mathrm{s}$ sea currents outside the marina, marina entrance widths of 10 and $40 \mathrm{~m}$, and for Rovinj and Dubrovnik locations $(L / B=2$ and $L / B=0.5)$

The tidal range at Rovinj is greater than that at Dubrovnik; thus, a lower concentration was observed after 48 $\mathrm{h}$ of the simulation compared to Dubrovnik for both entrance widths $(10 \mathrm{~m}$ and $40 \mathrm{~m})$. For the marina of $L / B=2$ at both locations, a slightly lower concentration is observed after a similar elapsed time compared to $L / B=0.5$. In areas with a lower tidal range, the width of the marina entrance has a significant influence on the water mass exchange compared to the areas of higher tidal range. The tidal range has bigger impact on the water mass exchange than the width of the marina entrance.

Figure 5 shows the vertically averaged concentration of fields (3D model) at an outer sea current velocity of $2 \mathrm{~cm} / \mathrm{s}$, E wind, and the marina entrance width of $40 \mathrm{~m}$, as well as for the $S$ wind and entrance width of $10 \mathrm{~m}$ at Rovinj and Dubrovnik locations $(L / B=2)$. The contribution of wind to the seawater exchange is more effective in the marina with wider entrance as opposed to the situations where the model was forced only by tides, where the 
seawater exchange was faster for narrower entrances. In addition, in the area of a smaller tidal range (Dubrovnik location), the contribution of wind to seawater exchange is higher than that at Rovinj.
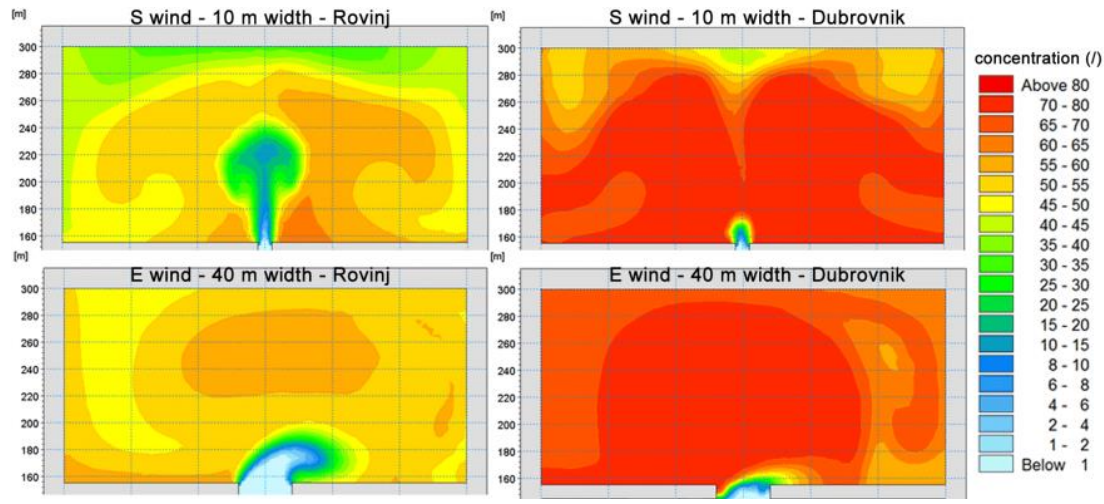

Figure 5 Vertically averaged concentration field fields (3D model) for the 96 th hour of numerical simulation at $2 \mathrm{~cm} / \mathrm{s}$ currents outside the marina, for the $E$ wind and the marina entrance width of $40 \mathrm{~m}$, and for the $S$ wind and entrance width of $10 \mathrm{~m}$, locations Rovinj and Dubrovnik ( $L / B=2)$

\subsection{Seawater exchange analyses}

Figure 6 shows a comparison of seawater volume exchanged through the marina entrance profile for the $2 \mathrm{D}$ model with variation of marina entrance width $(10,20,30,40 \mathrm{~m})$, and for the 3D model with marina entrance widths of 10 and $40 \mathrm{~m}$. In the first case, only tidal forcing was considered, whereas in the second case, tidal forcing was supplemented by wind action from five directions. The values were obtained through division with the maximum volume of exchanged seawater in the displayed set of simulation results (separately for 2D and 3D models). The dynamics of the mean tracer solution concentration in the marina basin during the simulation period (2D model) at Rovinj and Dubrovnik are shown in figure 7. The results are displayed for the marina entrance with widths of 10 and $40 \mathrm{~m}$ and currents outside the marina of $0,1,2$, and $5 \mathrm{~cm} / \mathrm{s}$ (ratio $L / B=2$ and $L / B=0.5$ ). Furthermore, the effect of the forced circulation at location Dubrovnik is shown to reach the e-flushing time in 10 days.

Figure 6 shows that at both locations (Rovinj and Dubrovnik) as well as model forced by tide and by both tide and wind, larger volume of exchanged seawater is achieved for the wider marina entrances. Similar conclusions were found in [25]. By increasing the width of the marina entrance owing to wind action, the volume of exchanged seawater increased by $71 \%$ (for all analyzed variants) [25]. In the case of only tidal forcing, for both locations, a slightly larger volume of the exchanged seawater is achieved for the marina with ratio $L / B=0.5$. Wind forcing (from all directions) causes a larger volume of seawater to pass through the marina entrance (for both locations), in regards to the case forced only by tides. A more significant contribution of the wind to the seawater volume exchange is evident for the location of Dubrovnik, an area with a smaller tidal range.
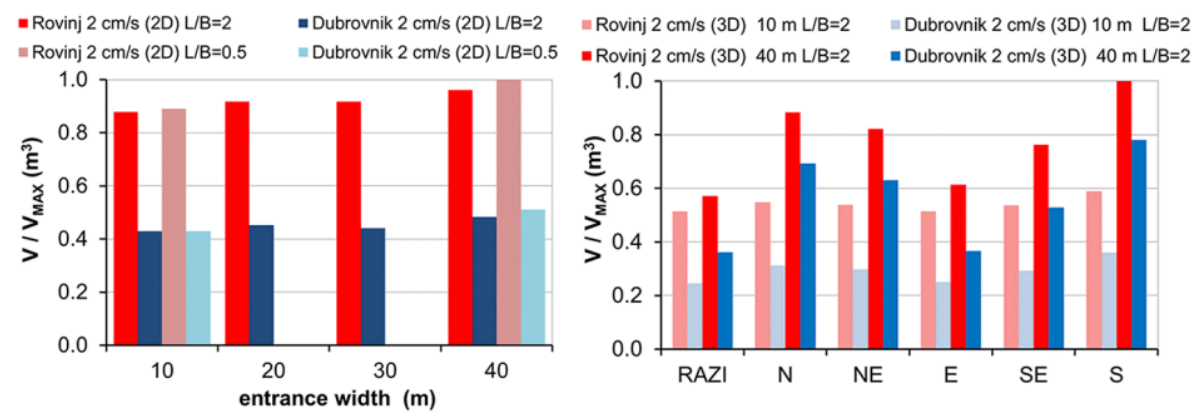

Figure 6 Comparison of the exchanged seawater volume through the marina entrance profile for the: 2D model after $240 \mathrm{~h}$ (10 days) of simulation with variation of marina widths and tidal forcing (left) and for the 
3D model after $144 \mathrm{~h}$ ( 6 days) of simulation for the marina entrance widths of 10 and $40 \mathrm{~m}$, tidal and wind forcing (5 wind directions); locations Rovinj and Dubrovnik, currents outside the marina of $2 \mathrm{~cm} / \mathrm{s}$

The sea current velocity outside the marina has a relatively small influence on the change in the concentration of the tracer solution for the marina with a $10 \mathrm{~m}$ entrance width (Figure 7). For the marina with a $10 \mathrm{~m}$ entrance width, the concentration of the mean tracer solution is approximately the same for the outside current of 1,2 , and $5 \mathrm{~cm} / \mathrm{s}$, while for the $0 \mathrm{~cm} / \mathrm{s}$ the water mass exchange is approximately $10 \%$ slower (for both locations). For the 40 $\mathrm{m}$ entrance width, the sea exchange was slower in the case of a current velocity of $0 \mathrm{~cm} / \mathrm{s}$ compared to other velocities $(1,2$, and $5 \mathrm{~cm} / \mathrm{s})$ by approximately $25 \%$. Note that the flow velocities in real conditions outside the marina are never $0 \mathrm{~cm} / \mathrm{s}$.

Figure 7 shows that the dynamics of the mean tracer solution concentration is the most unfavourable for the marina with a $40 \mathrm{~m}$ entrance width at Dubrovnik ( $L / B=2$ and outer sea current $0 \mathrm{~cm} / \mathrm{s})$. Meanwhile, the maximum volume of the exchanged seawater is achieved compared to marinas of entrance width 10,20 and $30 \mathrm{~m}$ for the same location (Figure 6). The fastest seawater exchange is achieved at Rovinj with entrance width of $10 \mathrm{~m}(L / B=2$ and currents outside the marina of $5 \mathrm{~cm} / \mathrm{s}$ ), for which the minimum volume of the exchanged seawater through the marina entrance is achieved (in comparison to the marina entrance widths of 20,30 and $40 \mathrm{~m}$ for the same location). A larger volume of seawater passing through the marina entrance does not necessarily indicate a lower tracer solution concentration in the case of only tidal forcing. This conclusion is valid for the tested marina entrance widths $(10 \mathrm{~m}, 20 \mathrm{~m}, 30 \mathrm{~m}$, and $40 \mathrm{~m}$ ) because the further narrowing of the entrance can again reduce the seawater exchange. Previous research [6] also recommends the narrow entrance if the circulation is primarily based on tidal oscillations and wide marina entrance, where currents or wind stress dominate [26]

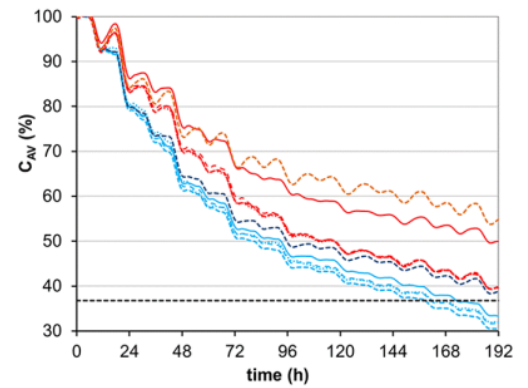

- $10 \mathrm{~m} \_$R_ $0 \mathrm{~cm} / \mathrm{s}(2 \mathrm{D}) L / \mathrm{B}=2$ $10 \mathrm{~m} \_$R_ $2 \mathrm{~cm} / \mathrm{s}(2 \mathrm{D}) \mathrm{L} / \mathrm{B}=2$ 10m_R_2 cm/s (2D) L/B $=0.5$ 40m_R_1 cm/s (2D) L/B-2

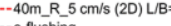

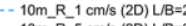
$10 \mathrm{~m} \_R \_$
$-40 m_{-} R_{-} 0 \mathrm{~cm} / \mathrm{s}(2 \mathrm{D}) \mathrm{L} / \mathrm{B}=2$ $40 \mathrm{~m} \_R \_2 \mathrm{~cm} / \mathrm{s}(2 \mathrm{D}) \mathrm{L} / \mathrm{B}=2$
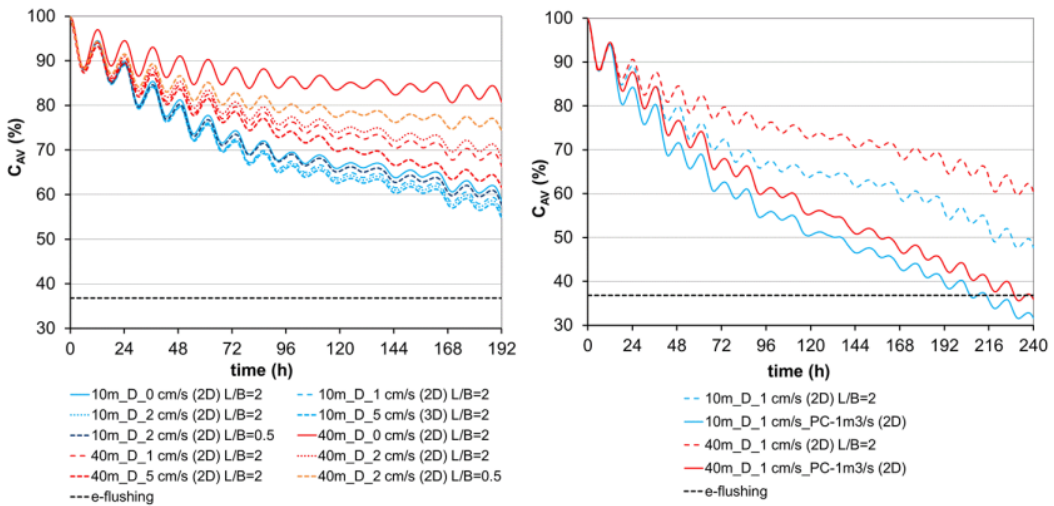

Figure 7 Mean tracer solution concentration in the marina basin during the simulation period: of $192 \mathrm{~h}$ ( 8 days) at Rovinj (left) and Dubrovnik (middle), for marina entrance widths of 10 and $40 \mathrm{~m}$, outer sea current speed of $0,1,2$ and $5 \mathrm{~cm} / \mathrm{s}$ (ratio $L / B=2$ and $L / B=0.5$ ) and during the simulation period of $40 \mathrm{~h} \mathrm{(10}$ days) for the marina entrance widths of $10 \mathrm{~m}$ and $40 \mathrm{~m}$ and currents outside the marina of $1 \mathrm{~cm} / \mathrm{s}$, at Dubrovnik with forced circulation intensity of $2 \times 0.5 \mathrm{~m}^{3} / \mathrm{s}$ (ratio $L / B=2$ ) (right) (all for $2 \mathrm{D}$ model)

To provide the complete water exchange of the basin between four and ten days (a condition characterized as "fair") at Dubrovnik, forced circulation with the flow rate of $2 \times 0.5 \mathrm{~m}^{3} / \mathrm{s}$ in the night mode was assumed. An eflushing time of 10 days was achieved even for a $40 \mathrm{~m}$ wide entrance. Forced circulation has a more significant impact on the e-flushing time than the entrance width. Instead of forced circulation, it is possible to use pipe culverts in the breakwater body to improve seawater exchange in micro-tidal areas $[25,27,28]$. Seawater exchange through culverts can be significantly accelerated by wind and wave forcing $[27,28]$. The use of forced circulation or pipe culverts to achieve better circulation will depend on the hydro-meteorological conditions at the location. 

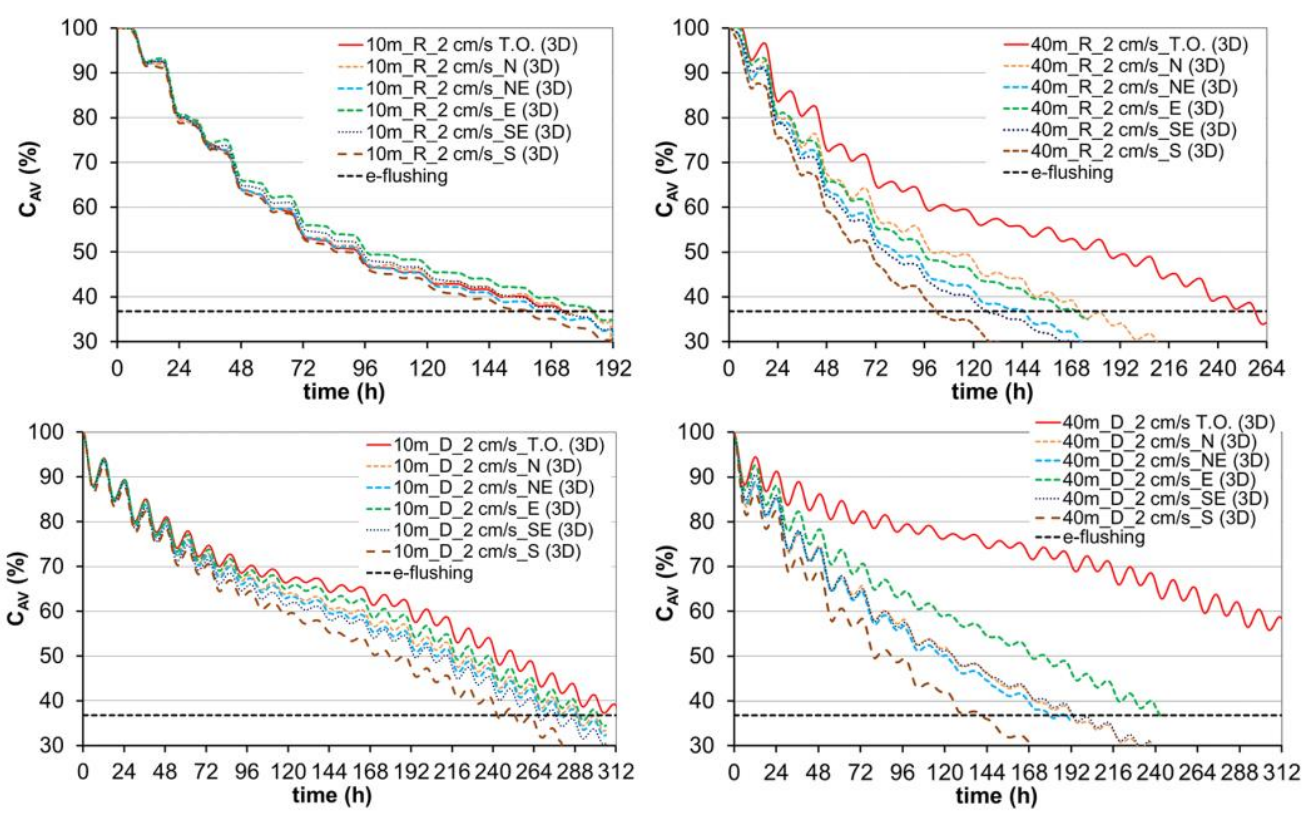

Figure 8 Dynamics of the mean tracer solution concentration in the marina basin during the simulation period at the locations Rovinj (up) and Dubrovnik (down), for the marina entrance widths of 10 (left) and $40 \mathrm{~m}$ (right) (outer sea current speed of $2 \mathrm{~cm} / \mathrm{s}, L / B=2$ ) for the case of tidal oscillations (T.O.) and wind from N, NE, E, SE and S direction (all for 3D model)

Wind forcing has a positive effect on the water mass exchange when increasing the width of the marina entrance (Fig. 8), contrary to the situations where the models were forced only by tides. The e-flushing time for the model forced only by tides, with the entrance width of $10 \mathrm{~m}$ at both locations, is on average 1.04 times longer in relation to situations forced by wind (averaged for all wind directions). For the $40 \mathrm{~m}$ wide entrance, the e-flushing time was approximately 1.89 times longer at Rovinj and 3.27 times at Dubrovnik location for all wind directions. The volume of the exchanged seawater through the marina entrance of $10 \mathrm{~m}$ width in the models forced by wind is approximately 1.06 times higher for Rovinj and 1.43 for Dubrovnik in relation to only tidal forcing. For the $40 \mathrm{~m}$ wide entrance, both locations had a volume of approximately 1.43 and 1.66 times higher, respectively. Furthermore, the percentages indicate that the entrance width is a significant factor for the sea exchange in the areas where wind generates flow. In the areas of smaller tides (location Dubrovnik), the effect of wind on the e-flushing time is more dominant in relation to the location of higher tidal ranges (Rovinj).

\subsection{Determination of the return flow factor}

According to Equation 3 for determining the e-flushing time $T_{f}$, in addition to determining the volume of the water in the marina basin $\left(V_{A K}\right)$, the period of tides $\left(T_{P O}\right)$, and the volume of the tidal prism $\left(V_{P O}\right)$, it is necessary to determine the return flow factor $b$. If equation 3 is used to determine the value of the return flow factor $b$, then it is important to know the values of $V_{P O}, V_{A K}, T_{P O}$, and $T_{f}$. For the specific cases of Rovinj and Dubrovnik, $V_{P O-A V}$ (ROVINJ) and $V_{P O-A V}$ (DUBROVNIK) were obtained by averaging hourly values of tidal amplitudes over the analyzed period of 10 days $\left(V_{P O-A V}\right.$ $\left(\right.$ ROVINJ) $\left.=17703 \mathrm{~m}^{3} ; V_{P O-S R \text { (DUBROVNIK) }}=8713 \mathrm{~m}^{3}\right)$. A half-day tidal period $\left(T_{P O}=12.42 \mathrm{~h}\right)$ occurs in the analyzed period; thus, it is possible to determine the value of coefficient $b$ depending on the arbitrary value of $T_{f}$. An illustration is provided in Figure 9. 
Table $1 T_{f}$ times for the sea currents outside the marina of 1,2 and $5 \mathrm{~cm} / \mathrm{s}$, with adopted averaged time $T_{f}$ and associated return flow factor $b$ for the entrance width of 10, 20,30 and $40 \mathrm{~m}(\mathrm{~L} / \mathrm{B}=2)$ and locations Rovinj and Dubrovnik

\begin{tabular}{|c|c|c|c|c|c|c|c|c|c|c|}
\hline & \multicolumn{5}{|c|}{ Rovinj } & \multicolumn{5}{|c|}{ Dubrovnik } \\
\hline & & & $\mathrm{T}_{\mathrm{f}}[\mathrm{h}]$ & & & & & $\mathrm{T}_{\mathrm{f}}[\mathrm{h}]$ & & \\
\hline width [m] & $1 \mathrm{~cm} / \mathrm{s}$ & $2 \mathrm{~cm} / \mathrm{s}$ & $5 \mathrm{~cm} / \mathrm{s}$ & $\mathrm{T}_{\mathrm{f}-\mathrm{AV}}[\mathrm{h}]$ & b & $1 \mathrm{~cm} / \mathrm{s}$ & $2 \mathrm{~cm} / \mathrm{s}$ & $5 \mathrm{~cm} / \mathrm{s}$ & $\mathrm{T}_{\mathrm{f}-\mathrm{AV}}[\mathrm{h}]$ & b \\
\hline 10 & 162 & 162 & 160 & 161 & 0 & 300 & 285 & 280 & 288 & 0 \\
\hline 20 & 161 & 160 & 160 & 160 & 0 & 292 & 291 & 290 & 291 & 0 \\
\hline 30 & 186 & 186 & 184 & 185 & 0.06 & 342 & 339 & 328 & 336 & 0 \\
\hline 40 & 209 & 209 & 210 & 209 & 0.18 & 389 & 378 & 389 & 385 & 0.08 \\
\hline
\end{tabular}

In Table 1, the $T_{f}$ values are shown for sea currents of 1,2 , and $5 \mathrm{~cm} / \mathrm{s}$ outside the marina with corresponding averaged $T_{f}$ time and associated return flow factor for the marina entrance widths of 10, 20,30, and $40 \mathrm{~m}$ at both locations. The values of the return flow factor $b$ indicate that as the entrance width increases, the return flow factor also increases. For marinas with wider entrances, the possibility of returning "old" seawater to the marina is greater. In addition, in the area of higher tidal range, i.e., larger seawater exchange between marina and sea outside the marina, the return flow factor is slightly higher.

Expression 3, which was used to determine the return flow factor $b$, considers only tides, and the effect of wind on factor $b$ cannot be accounted for using this method. However, because the wind forcing decreases with time $T_{f}$, it can be assumed that factor $b$ will decrease too, which is a subject of further research.

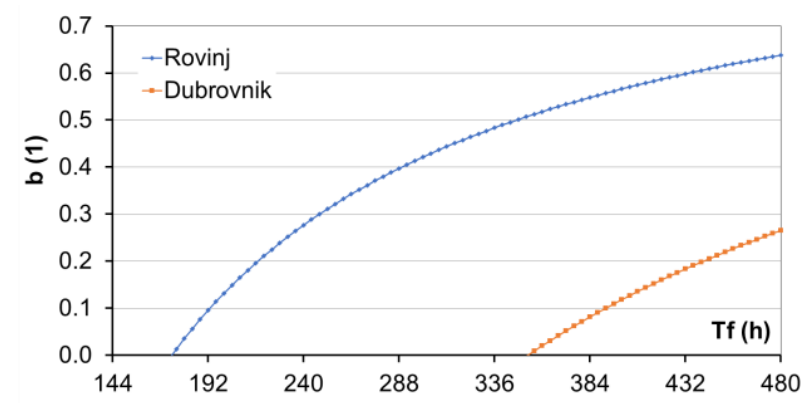

Figure 9 Values of return flow factor $b$ in relation to $T_{f}$ (half day tidal period $-12.42 \mathrm{~h} V_{P O-S R \text { (ROVINJ) }}=17703$ $\mathrm{m}^{3} ; V_{P O-S R}$ (DUBROVNIK) $=8713 \mathrm{~m}^{3}$ )

\section{CONCLUSION}

The flushing characteristics study of a hypothetical marina was conducted on 2D (influence of tides) and 3D (forced by tides and N, NE, E, SE, and S wind) numerical models to determine the return flow factor $b$. The analysis includes the influence of tidal range, the width of the marina entrance, the marina length/width ratio, and the wind forcing impact. Besides the above-mentioned generators, the case of forced circulation (generated by the operation of a low-pressure pump) was analyzed.

The 2D model results (forced only by tides) show that the marina entrance width (for both locations and both $L / B$ ratios) has only a local impact on the vertical averaged current velocity field. Higher velocities occur in the marina with narrower entrance $\left(P_{a k} / A_{u}>200\right)$, and a larger seawater exchange is achieved. In areas with smaller tidal ranges, the width of the marina entrance has a stronger influence on seawater exchange compared to areas with larger tidal ranges. The tidal range has a more significant impact on the seawater exchange than the variation in the marina entrance width. The current velocity outside the marina, greater than $0 \mathrm{~cm} / \mathrm{s}$, does not have a major influence on the $T_{f}$ time. At both locations and for both entrance widths, faster sea exchange was achieved for the marina with a $L / B$ ratio of 2 than with $L / B=0.5$. The largest volume of the exchanged sea does not necessarily indicate the fastest sea exchange (in the form of reaching time $T_{f}$ ). Besides the natural circulation generators, it is possible to include forced circulation (low-pressure pump) to achieve time $T_{\mathrm{f}}<10$ days, even at Dubrovnik location, where the $T_{f}$ time is the longest. The results of the $3 \mathrm{D}$ models show that wind accelerates circulation in the marina 
and the exchange of seawater, especially where smaller tidal ranges are present (Dubrovnik). The velocities in the models forced by wind are higher in the marina with wider entrances. The return flow factor $b$ depends on the width of the marina entrance, less on the tidal signal amplitude, and least on the current velocity outside the marina. In areas with lower tidal ranges and centrally positioned marina entrances, where the wind influence is negligible, it is necessary to provide a narrow marina entrance for faster sea exchange. In such cases, it is also possible to implement forced circulation using a pump to achieve a satisfactory sea exchange. In areas where wind action may contribute to sea exchange, a wider entrance to the marina is recommended.

\section{References}

[1] Fischer H.B. et al. 1979: Mixing in inland and coastal waters. Academic Press, San Diego, California, USA

[2] Schwartz R.A.; Imberger J. 1988: Flushing behaviour of a coastal marina, In 21st International Conference on Coastal Engineering Proceedings. https://doi.org/10.1061/9780872626874.196

[3] Nece R.A. 1984: Planform effects on tidal flushing of marinas, Journal of waterway, port, coastal, and ocean engineering, 110 (2), pp. 251-269. https://doi.org/10.1061/(ASCE)0733-950X(1984)110:2(251)

[4] Falconer R.A; Guoping Y.; Yu, G. 1991: Effects of depth, bed slope and scaling on tidal currents and exchange in a laboratory model harbour, In Proceedings of the Institution of Civil Engineers, 91 (3), pp. 561-576. https://doi.org/10.1680/iicep.1991.15630

[5] US Army Corps of Engineers, 2002: Coastal Engineering Manual (CEM), EM 1110-2-1100.

[6] Recreational navigation Commission (PIANC), 2008: Protecting water quality in marinas, Report $n 98$.

[7] US Environmental Protection Agency. 1985. Coastal Marinas assessment Handbook. Atlanta GA.: U.S. Enviromental Protection Agency, Region 4.

[8] Carević, D.; Bujak, D.; Lončar, G.; Bartolić, I., 2019: Use of culverts for improving exchange of seawater in ports, Građevinar, 71(3), pp.197-207. https://doi.org/10.14256/JCE.2527.2018

[9] Bujak, D.; Carević, D.; Mostečak, H., 2017: Velocities inside flushing culverts induced by waves, In Proceedings of the Institution of Civil Engineers-Maritime Engineering, 170 (3+4), pp. 112-121, Thomas Telford Ltd. https://doi.org/10.1680/jmaen.2017.15

[10] Carevic, D.; Mostecak, H.; Bujak, D.; Loncar, G. 2018: Influence of water level variations on wave transmission through flushing culverts positioned in breakwater body. Journal of Waterway, Port, Coastal, and Ocean Engineering, 144 (5), 04018012. https://doi.org/10.1061/(ASCE)WW.1943-5460.0000464

[11] Agresti V., 2018: Effects of tidal motion on the Mediterranean Sea General Circulation, doctoral thesis.

[12] Defant A., 1961: Physical Oceanography. Pergamon Press New York.

[13] Monsen N.E.; Cloern J.E.; Lucas L.V.; Monismith S.G. 2002: A comment on the use of flushing time, residence time, and age as transport time scales, Limnology and oceanography, 47 (5), pp. 1545-1553. http://dx.doi.org/10.4319/lo.2002.47.5.1545

[14] Schmidt L.D. 2005: Engineering of Chemical Reactions, Eng Chem React. :601-5.

[15] Sanford L.P.; Boicourt W.C.; Rives S.R. 1992: Model for Estimating Tidal Flushing of Small Embayent, Journal of Waterway, Port, Coastal, and Ocean Engineering, 118 (6), pp. 635-654. https://doi.org/10.1061/(ASCE)0733-950X(1992)118:6(635)

[16] Luketina D. 1998: Simple Tidal Prism Models Revisited. Estuarine, Coastal and Shelf Science, 46 (1), pp. 77 84. https://doi.org/10.1006/ecss.1997.0235

[17] Carević, D.; Lončar, G.; Kuspilić, N., 2014: Tehničko ekonomski parametri marina u Hrvatskoj, Građevinar. 66 (10), pp. 909-915. https://doi.org/10.14256/JCE.1110.2014

[18] Cucco, A.; Umgiesser G. 2006: Modeling the Venice Lagoon residence time, Ecological modelling, 193 (1-2), pp. 34-51. https://doi.org/10.1016/i.ecolmodel.2005.07.043

[19] DHI MIKE 21 \& MIKE 3 FLOW MODEL FM, 2010: Hydrodynamic Module Scientific Documentation, p. 96. www.mikebydhi.com Accessed 28 December 2020

[20] Song, Y.; Haidvogel, D. 1994: A semi-implicit ocean circulation model using a generalised topographyfollowing coordinate system, Journal of Computational Physics, 115 (1), pp. 228-244. https://doi.org/10.1006/icph.1994.1189

[21] Janeković, I.; Kuzmić M. 2005: Numerical simulation of the Adriatic Sea principal tidal constituents, In Annales Geophysicae, 23 (10), pp. 3207-3218, Copernicus GmbH. https://doi.org/10.5194/angeo-23-3207-2005 
[22] Rodi W. 1987: Examples of calculation methods for flow and mixing in stratified fluids, Journal of Geophysical Research: Oceans, 92 (C5), pp. 5305-5328. http://doi.wiley.com/10.1029/JC092iC05p05305

[23] Smagorinsky J. 1993: Some historical remarks on the use of nonlinear viscosities, Large eddy simulation of complex engineering and geophysical flows, 1, pp. 69-106.

[24] Wu J. 1994: The sea surface is aerodynamically rough even under light winds, Boundary-layer meteorology, 69 (1-2), pp. 149-158. https://doi.org/10.1007/BF00713300

[25] Lončar, G.; Carević, D.; Bujak, D.; Bartolić, l.; Beg Paklar, G., 2017: Analiza utjecaja vjetra, plimnih oscilacija i razdiobe gustoće na izmjenu mora kroz propuste u marinama : primjer marine lčići, Hrvatske Vode, 25(101), pp. 139-148.

[26] Nece, R.; Richey E.P.; Rhee, J.; Smith, H.N. 1981: Effects of Planform geometry on tidal flushing and mixing in marinas, Environmental Research Laboratory.

[27] Lončar, G.; Bekić, D.; Carević, D.; Bujak, D.; Bartolić, l.; Beg Paklar, G., 2016: Utjecaj kanalskih propusta na izmjenu mora i valovanje u akvatoriju marina, Hrvatske Vode, 24 (98), pp. 275-284.

[28] Lončar, G.; Bartolić, I; Bujak, D., 2018: Contribution of wind and waves in exchange of seawater through flushing culverts in marinas, Tehnički Vjesnik, 25 (6), pp. 1587-1594. https://doi.org/10.17559/TV$\underline{20160912211937}$

Please cite this article as: Bartolić, l.; Lončar, G.: Bujak, D.; Carević, D.: Numerical investigations of flushing time in small marinas, Electronic Journal of the Faculty of Civil Engineering Osijek-e-GFOS, 2020, 21, pp. 55-66, https://doi.org/10.13167/2020.21.5 